JPdK Volume 1 No 1 Tahun 2019 Halaman 69-77

JURNAL PENDIDIKAN dan KONSELING

Research \& Learning in Primary Education

UNNIVERSITAS

\title{
Pengembangan Model Bercerita Berbasis VAK Untuk Memfasilitasi Kemamapuan Menyimak Anak Pada Kelompok B Taman Kanak-Kanak
}

\author{
Annisa Shofaril Wahidah'1, Edi Hendri Mulyana², Yasbiati ${ }^{3}$ \\ Pendidikan Guru Pendidikan Anak Usia Dini \\ Fakultas Ilmu Pendidikan \\ Universitas Pendidikan Indonesia Kampus Tasikmalaya \\ Email:shofarilannisa@gmail.com,
}

\begin{abstract}
Abstrak
Penelitian ini didasarkan pada hasil studi pendahuluan yang telah dilakukan oleh peneliti mengenai kegiatan bercerita yang selama ini dilakukan oleh guru dalam pembelajaran. Berdasarkan lapangan, kegiatan bercerita belum dijadikan sarana pengajaran oleh guru dalam penyampaian tema secara utuh. Kenyataannya kegiatan bercerita hanya digunakan untuk penambah kegiatan diawal atau diakhir saja. Karenanya model pembelajaran yang digunakan guru melalui kegiatan bercerita belum terealisasi dengan baik. Hal ini berdampak pada perkembangan anak yang belum optimal dalam pembelajaran. Sedangkan anak usia dini menaruh minat yang besar terhadap kegiatan bercerita tersebut. Maka peneliti mengembangkan model bercerita sesuai kebutuhan gaya belajar siswa yang dapat memfasilitasi salah satu keterampilan dasar berbahasa anak yaitu kemampuan menyimak. Tujuan dari penelitian ini adalah memberikan panduan pengajaran melalui bercerita kepada guru untuk memfasilitasi perkembangan anak sehingga dapat mencapai hasil belajar yang diharapkan. Dikarenakan kegiatan bercerita ini berorientasi pada kebutuhan modalitas anak, maka peneliti menyusun tahapan bercerita berbasis visual auditori kinestetik (VAK). Metode penelitian yang digunakan dalam penelitian ini adalah metode Educational Design Research (EDR) model McKenney\& Reaves. Teknik pengumpulan data yang digunakan yaitu wawancara, observasi, audio dan visual, serta validasi dari ahli. Instrumen divalidasi oleh ahli model pembelajaran anak usia dini dan ahli bahasa dan melalui beberapa revisi sesuai saran validator. Setelah validasi internal dilakukan, selanjutnya penelitian ini melalui tahap validasi eksternal yang dilakukan selama dua kali uji coba di TK Artanita Al-Khairiyah. Secara umum, model bercerita berbasis VAK ini layak digunakan dan menghasilkan produk model bercerita berbasis VAK untuk memfasilitasi kemampuan menyimak anak pada kelompok B taman kanak- kanak.
\end{abstract}

Kata Kunci: Bercerita, VAK, kemampuan menyimak, Educational Design Research

\begin{abstract}
This research is based on the results of preliminary studies conducted by researchers regarding the storytelling activities that have been carried out by the teacher in learning. Based on the field, storytelling activities have not been used as teaching facilities by teachers in delivering the themes in their entirety. In fact storytelling activities are only used to increase activities at the beginning or end. Therefore the learning model used by
\end{abstract}


teachers through storytelling activities has not been well realized. This has an impact on children's development that has not been optimal in learning. While early childhood put a great interest in the storytelling activity. So the researcher developed a storytelling model according to the students' learning style needs that could facilitate one of the basic skills of children's language, namely listening skills. The purpose of this study is to provide teaching guidance through telling teachers to facilitate children's development so that they can achieve the expected learning outcomes. Because this storytelling activity is oriented to the needs of child modalities, the researcher composes the stages of visual auditory kinesthetic (VAK) storytelling. The research method used in this study is the Educational Design Research (EDR) method of McKenney \& Reaves. Data collection techniques used were interviews, observation, audio and visual, and validation from experts. The instrument was validated by early childhood learning model experts and linguists and through several revisions according to the validator's suggestions. After internal validation is carried out, then this research through the external validation stage which was carried out during two trials at Artanita Al-Khairiyah Kindergarten. In general, the VAK-based storytelling model is feasible to use and produces a VAK-based storytelling product model in facilitating the ability to listen to children in kindergarten group B.

Keywords: Storytelling, VAK, listening ability, Educational Design Research

\section{PENDAHULUAN}

Seorang anak akan melewati tahaptahap perkembangan dengan tugas perkembangan yang berbeda-beda, dimana keberhasilan pencapaian suatu tugas perkembangan disuatu tahap akan menolong kelancaran tahap berikutnya. Hal ini menunjukkan bahwa anak dikatakan berkembang secara normal apabila anak dapat menyelesaikan tugas- tugas yang harus dijalaninya pada masa tersebut. Sebaliknya apabila anak tidak mampu menyelesaikan tugas-tugas yang harus dijalaninya maka dapat dikatakan bahwa anak mengalami hambatan dalam perkembangannya (Roestiyah, 2008. him 12). Pada tugas aspek bahasa, perkembangan bahasa anak bukan hanya soal memberi penghargaan kepadanya karena ia berucap benar dan meniru seorang pembicara atau guru. Anak-anak akan lebih cerdas berbahasa jika orang tua dan guru secara aktif melibatkan anak-anak dalam percakapan, memberi mereka pertanyaan, dan menekankan bahasa interaktif ketimbang bahasa perintah. (Santrock, 2017, hlm. 70). Sejalan dengan itu, menurut Piaget (dalam Rusman, 2017, hlm. 124) mengenai teori perkembangan kognitif pada usia pra operasional, kemampuan anak dalam berbahasa difase ini mulai berkembang. Karena melalui pengalamannnya anak dapat mengenal dan memberikan objek dengan nama- nama sesuai dengan gagasan yang telah dibentuknya dalam otak. Anak akan mampu mengekspresikan sesuatu dengan kalimat pendek namun efektif.

Namun di suatu lembaga pendidikan anak usia dini yang terdapat di Kecamatan Cihideung pada usia kelompok B, peneliti menemukan masalah bahwa guru mendapati kesulitan dalam menarik perhatian anak ketika bercerita hingga cerita itu selesai disampaikan. Padahal pada awalnya, anak memiliki ketertarikan dan antusias yang bagus saat guru memberikan penerangan bahwa ia akan melakukan kegiatan bercerita. Berdasarkan hasil observasi yang telah dilakukan, peneliti memerhatikan bahwa guru cenderung seperti menasehati dan mendikte teks cerita tersebut kepada anak. Guru belum menguasai teknik-teknik yang dapat 
diaplikasikan untuk menghidupkan suasana bercerita yang berdampak semakin menurunnya perhatian dan minat anak saat mendengarkan cerita yang disampaikan. Sehingga esensi dari menyimak cerita itu sendiri belum terjangkau karena tujuan pembelajaran dan nilai yang ingin dicapai dalam cerita tersebut belum dapat terealisasi dengan baik.

Sedangkan menurut penelitian Stockall

dan Dennis (2012, hlm. 2) bahwa "Meaningful literacy activities don't have to be passive or sedentary types interactions". Akibatnya

kemampuan menyimak anak menjadi belum berkembang secara optimal. Hal tersebut dapat terlihat pada pengobservasian yang seharusnya anak menyimak cerita, ia terlihat mulai kurang memfokuskan perhatiannya pada cerita guru. Anak cenderung membagi perhatiannya pada kegiatan lain disekitarnya dan anak lebih memilih berbicara sendiri bahkan beberapa anak terlihat senang mengobrol dengan teman disampingnya. Selain itu, dikegiatan konfirmasi, masih banyak ditemukan anak yang belum bisa menjawab pertanyaan guru terkait dengan cerita yang telah disampaikan. Sedangkan kemampuan menyimak merupakan kemampuan dasar dalam keterampilan berbahasa yang harus dimiliki setiap anak, karena empat keterampilan bahasa yang menjadi tingkatan bagi anak yaitu menyimak, berbicara, membaca, menulis.

Menilik pada karakteristik anak usia dini menurut Cross (2013) permasalahan hambatan menyimak pada anak usia dini juga sangat dimungkinkan karena anak memiliki daya perhatian yang pendek, yang artinya anak kecenderungan memiliki perhatian yang pendek, kecuali pada hal-hal intrinsik yang menyenangkan. la masih sulit untuk duduk dan memerhatikan sesuatu untuk jangka waktu yang lama. Berg (dalam Madyawati, 2017. hlm 15) menegaskan, bahwa "Sepuluh menit merupakan waktu yang wajar bagi anak berusia lima tahun untuk dapat duduk dan memerhatikan sesuatu secara nyaman". Berdasarkan hal tersebut, upaya untuk mendorong kemampuan menyimak anak dengan daya perhatian yang dimilikinya bisa dilakukan oleh berbagai cara, salah satunya melalui kegiatan bercerita yang menyenangkan. Maka dari itu guru tidak hanya memerlukan metode atau strateginya saja. Namun guru memerlukan panduan kegiatan yang lengkap dan sistematis. Sebagaimana hasil temuan peneliti berdasarkan penelitian terdahulu mengenai kegiatan bercerita bagi kemampuan bahasa anak, ditemukan ada hal yang belum tersentuh untuk dilakukan penelitian yaitu pengembangan produk bagi kegiatan bercerita dalam memfasilitasi kemampuan bahasa anak itu sendiri. Hal ini dikarenakan beberapa penelitian cenderung dilakukan melalui upaya metode bercerita saja dan cenderung dilakukan melalui metode PTK atau penelitian tindakan kelas, dan single case experimental (Fauziah, 2018; Meilana, 2018; Yulianti, 2018).

Hal lain yang diduga turut menentukan kemampuan menyimak melalui kegiatan bercerita adalah keunikan tersendiri yang dimiliki oleh anak yaitu seperti gaya belajar, minat, dan latar belakang keluarganya. Hal ini dikuatkan oleh beberapa pakar bahwa hak paling asasi bagi anak adalah ketika guru mengajar sesuai dengan gaya belajar dan modalitas belajar peserta didiknya (Bradekamp, 2007; Said dan Budimanjaya, 2017). Dalam hal ini, pengajaran yang dapat memberikan pembelajaran kepada anak sesuai dengan gaya belajar, salah satunya adalah model modalitas visual, auditori, dan kinestetik (VAK). Karena Markova, 1992 (dalam DePorter, 2007, hlm. 85) berpendapat bahwa "Orang tidak hanya cenderung pada satu modalitas, mereka juga memanfaatkan kombinasi modalitas tertentu yang memberi mereka bakat dan 
kekurangan alami tertentu". Sementara itu menurut DePorter (2007, hlm. 84) mengenai pengajaran berlandaskan modalitas VAK adalah "Betapa menguntungkannya jika Anda dapat menyesuaikan pengajaran Anda dengan modalitas-modalitas tersebut, secara harfiah berbicara dengan bahasa yang sama dengan otak pelajar anda".

Maka berlandaskan latar belakang masalah ini, peneliti terdorong untuk menawarkan solusi terhadap permasalahan tersebut dengan mengembangkan "Pengembangan Model Bercerita Berbasis VAK untuk Memfasilitasi Kemampuan Menyimak Anak Usia Dini pada Kelompok B Taman Kanak-Kanak". Diharapkan dengan adanya pengembang model pembelajaran dalam kegiatan bercerita ini, kemampuan menyimak anak dapat berkembang sesuai dengan kompetensi yang diharapkan.

Secara umum, penelitian ini dilakukan untuk mrngrmbangkan model bercerita berbasis VAK sebagai solusi bagi permasalahn yang dialami guru sebagai panduan dalam melaksanakan kegiatan bercerita. Oleh karenanya, penelitian ini menggunakan metode Educational Design Research (EDR). EDR merupakan sebuah pendekatan penelitian dengan menggunakan analisis data kuantitatif dan kualitatif (Herrington, Mckenney, Reeves, \& Oliver, 2007). Jan Van Den Akker, Koeno Gravemeijer, dkk (2006, hlm. 1) juga berpendapat bahwa Educational Design Research yaitu "Studi sistematis merancang, mengembangkan dan mengevaluasi program pendidikan, proses, produk". Sedangkan menurut Plomp (2010), Educational Design Research adalah:

Suatu kajian sistematis tentang merancang, mengembangkan dan mengevaluasi intervensi pendidikan (seperti program, strategi dan bahan pembelajaran, produk dan sistem) sebagai solusi untuk memecahkan masalah yang kompleks dalam praktik pendidikan, yang juga bertujuan untuk memajukan pengetahuan kita tentang karakteristik dari intervensi- intervensi tersebut serta proses perancangan dan pengembangannya (Plomp, 2010)

Pada pengembangan proses penelitian ini, peneliti menggunakan model pengembangan EDR versi McKenney \& Reaves. Adapun model generik EDR tersebut adalah sebagai berikut ini:

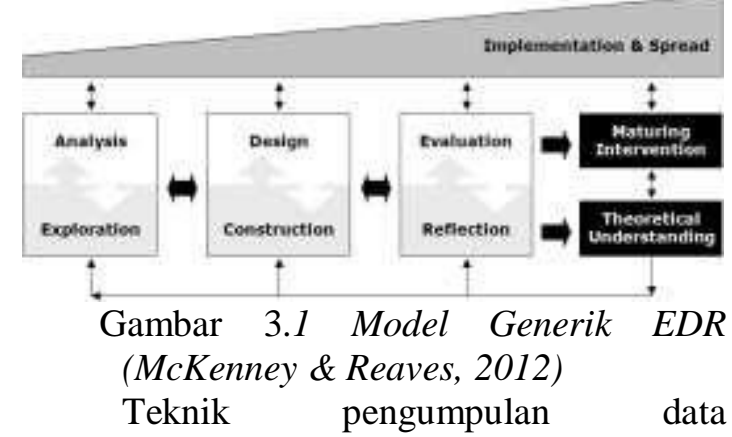
menggunakan wawancara, observasi, audio dan visual, serta expert judgement. Penganalisisan data pada penelitian ini, peneliti menggunakan analisis data model Miles dan Huberman. Miles dan Huberman (dalam Sugiyono, 2017, hlm.

337) menyatakan bahwa "Aktivitas dalam analisis data kuaJitatif dilakukan secara interaktif dan berlangsung secara terus menerus sampai tuntas, sehingga datanya sudah jenuh". Adapun komponen analisis data berdasarkan model Miles dan Huberman terdiri dari reduksi data, penyajian data, dan penarikan kesimpulan/verifikasi. "We see analysis are three concurrent flows of activity: (1) data condensation, (2) data display, (3) conclusion drawing/verification" (Miles dan Huberman, 2014)

\section{HASIL DAN PEMBAHASAN}
A. Analysis and Exploration
Kebutuhan akan panduan bercerita yang baik di lapangan sangat dibutuhkan, terutama untuk memfasilitasi kemampuan 
bahasa anak. Sebagaimana pada hasil studi pendahuluan yang telah dilakukan oleh peneliti di TK Artanita Al-Khairiyah pada kelompok B bahwa guru belum bisa menyampaikan cerita dengan menarik karena masih kurangnya persiapan dalam melaksanakan bercerita dan anak anak belum dapat menyimak dengan baik. Hal ini dibuktikan saat anak diminta untuk menceritakan kembali atas cerita yang telah disampaikan, ia belum bisa melaksanakannya. Padahal anak pada usia 56 tahun diharapkan dapat mencapai kemampuan menyimak sesuai indikator yang telah dituliskan dalam Permendikbud Nomor 146 Tahun 2014 tentang Kurikulum 2013 PAUD yaitu dapat menceritakan kembali apa yang didengar dengan kosakata yang lebih dan melaksanakan perintah yang lebih kompleks sesuai dengan aturan yang disampaikan (Mendikbud RI. 2014, hlm. 30 31).

Pada dasarnya apabila cerita tersebut dapat tersampaikan dengan baik, maka kegiatan bercerita itu memiliki manfaat terutama bagi perkembangan bahasa anak. Sebagaimana Madyawati (2016, hlm. 167), menegaskan manfaat bercerita bagi anak diantaranya adalah sebagai berikut:

a) Membantu pembentukan pribadi dan moral anak. Cerita sangat efektif membentuk pribadi dan moral anak. Melalui cerita, anak dapat memahami nilai baik dan buruk yang berlaku pada masyarakat.

b) Menyalurkan kebutuhan imajinasi dan fantasi. Cerita dapat dijadikan sebagai media menyalurkan imajinasi dan fantasi anak. Pada saat menyimak cerita, imajinasi anak mulai dirangang. Imajinasi yang dibangun anak saat menyimak cerita memberikan pengaruh positif terhadap kemampuan anak dalam menyelesaikan masalah secara kreatif.

c) Memacu kemampuan verbal anak. Cerita dapat memacu kecerdasan linguistik anak. Cerita mendorong anak bukan saja senang menyimak cerita tetapi juga senang bercerita atau berbicara. Anak belajar tata cara berdialog dan bernarasi.

Maka berdasarkan teori tersebut, peneliti mengembangkan model bercerita berbasis gaya belajar siswa yang dibutuhkan oleh anak anak sebagai sasaran proses bercerita tersebut di lapangan untuk memenuhi kebutuhan lapangan akan panduan bercerita yang dapat menarik dan bermanfaat bagi perkembangan bahasa anak. Realisasi yang dilakukan melalui penelitian ini sudah terpenuhi untuk memfasilitasi kemampuan menyimak anak dengan upaya kegiatan bercerita, dan karenanya guru dapat mengaplikasikannya dengan baik.

\section{B. Design and Construction}

Merancang produk ini, peneliti berpacu pada model pembelajaran kebutuhan modalitas siswa. Dengan berdasarkan model pembelajaran ini, diharapkan kegiatan bercerita dapat mewadahi kebutuhan siswanya sesuai gaya belajar yang telah dimilikinya. Hal ini ditegaskan oleh DePorter, 1999 (dalam Shoimin, 2014, hlm. 226) bahwa "Gaya belajar merupakan kombinasi dari bagaimana seseorang dapat menyerap dan kemudian mengatur serta mengolah informasi".

Model bercerita ini berprinsip pada sintaks (langkah langkah), prinsip reaksi, sistem sosial, dan sistem pendukung.

a) Sintaks

Sintaks merupakan suatu tahapan dalam model bercerita yang memuat langkahlangkah dalam melaksanakan kegiatan bercerita. Prinsip model bercerita ini memberikan panduan 
kegiatan apa yang akan dilakukan seorang guru dalam kegiatan bercerita.

b) Prinsip Reaksi

Prinsip reaksi model bercerita ini berkaitan dengan penyiapan aspek perencanaan, pelaksanaan, dan tindak lanjut/rencana penilaian.

c) Sistem Sosial

Sistem sosial dalam kegiatan bercerita ini terdiri atas pemberian tugas dari guru dan kegiatan siswa selama proses bercerita. Kegiatan bercerita ini memfokuskan pada keterampilan bahasa anak yang paing mendasar yaitu kemampuan menyimak. Sehingga anak mampu memerankan tugasnya dalam berpartasipasi menjadi penyimak yang aktif karena ikut serta berperan dalam proses kegiatan bercerita.

d) Sistem Pendukung

Prinsip kegiatan bercerita ditinjau dari dimensi sistem pendukung terdiri atas sumber belajar yang relevan dengan anak dan media pembelajaran. Sumber belajar yang digunakan dalam kegiatan bercerita tentunya bahan cerita yang mana tema dan tujuannya harus relevan dengan anak usia dini kelompok B. Bahan cerita juga harus memiliki komponen yang sesuai dengan tema dan kehidupan sehari hari anak yang sering ditemui agar nilai moral yang dimaksud tersampaikan dengan jelas dan langsung. Sedangkan media pembelajaran yang dapat dimanfaatkan dalam kegiatan bercerita ini diantaranya alat peraga. Media dapat membantu guru dalam menyampaikan cerita yang tidak monoton dan textbook.

Sedangkan perancangan produk ini teridiri dari perencanaan, pengembangan/pelaksanaan, serta evaluasi. Berdasarkan hasil pengembangan produk pada penelitian ini, rancangan sudah memenuhi sebagian kebutuhan teori dan lapangan dalam memfasilitasi kemampuan menyimak anak sesuai gaya belajarnya melalui kegiatan bercerita.

\section{Evaluation and Reflection}

Hasil perancangan awal produk ini telah diuji cobakan sekaligus sebagai validitas ekstemal guna mengetahui kelayakan dan kepraktisannya di lapangan. Sebagaimana menurut Pearl, 2014 (dalam Kumiawan, 2018, hlm. 131) bahwa "Validitas eksternal merupakan persoalan penelitian yang berkaitan dengan penanyaan, sejauh mana hasil suatu penelitian bisa digeneralisasikan pada populasi induk (asal sampel) di mana penelitian diambil atau validitas ekstemal berhubungan dengan generalisasi hasil penelitian". Maka dari itu, peneliti melaksanakan tahap uji coba hingga terbentuk produk yang diharapkan oleh bersama dan menghasilkan akhir produk yang optimal.

Pada uji coba tahap I, peneliti melakukan uji coba terbatas guna mengetahui keterpakaian awal sebelum guru mengaplikasikan rancangan tersebut. Setelah mengalami pertimbangan dan perbaikan oleh peneliti, pembimbing, serta guru terkait, maka tahap berikutnya dilakukan uji coba tahap I pada kelompok Bl di TK Artanita AlKhairiyah. Dalam kegiatan ini, guru menjadi praktikan dan peneliti menjadi observer. Dalam pelaksanaan tahap pelatihan, guru sempat mendapati kesulitan dalam mengondisikan anak anak saat ada suara bising dari kelas sebelah diluar dugaan. Akibatnya guru melewati langkah dalam memfasilitasi anak untuk mendemonstrasikan alat peraga dalam bercerita untuk segera mengondisikan anak anak dengan pemberian tugas LKA. Namun dikegiatan konfirmasi, sebagian besar anak-anak dapat menceritakan kembali apa yang telah didengar mengenai cerita tersebut dan dapat melaksanakan perintah saat guru memintanya. Capaian kemampuan menyimak anak kelompok B1 pada uji coba I adalah $67 \%$ berkembang sangat baik. 
Setelah melalui refleksi dan revisi dari uji coba tahap I, langkah yang dilakukan adalah menguji kembali produk pada uji coba tahap II. Pada tahap ini, peneliti lebih mempersiapkan persiapan yang akan digunakan oleh guru sebagai praktikan. Pada prosesnya, guru dapat melaksanakan langkah-langkah bercerita dan menggunakan sumber serta media yang telah disiapkan dengan baik dan benar. Hasilnya anak-anak dapat menyimak cerita dengan baik dan capaian kemampuan menyimak anak kelompok B2 pada uji coba II bahwa kemampuan menyimak anak kelompok B2 91,5\% berkembang sangat baik. Maka dari hasil temuan-temuan tersebut, penelitian ini menguatkan teori menurut DePorter (2007, hlm. 84) mengenai pengajaran berlandaskan modalitas VAK bahwa "Betapa menguntungkannya jika Anda dapat menyesuaikan pengajaran Anda dengan modalitas-modalitas tersebut, secara harfiah berbicara dengan bahasa yang sama dengan otak pelajar anda". Karenanya hasil pengembangan produk ini dapat memberikan manfaat salah satunya untuk meningkatkan kemampuan menyimak anak pada usia kelompok B.

\section{SIMPULAN}

Berlandaskan hasil penelitian pengembangan model bercerita berbasis VAK untuk memfasilitasi kemampuan menyimak anak usia dini pada kelompok B taman kanak-kanak yang telah dilakukan, maka dapat diperoleh kesimpulan sebagai berikut ini:

A. Kebutuhan serta kekurangan yang belum tersedia untuk melaksanakan kegiatan bercerita dalam memfasilitasi kemampuan menyimak anak pada kelompok B taman kanak kanak adalah model bercerita berupa panduan bagi guru. Belum adanya arahan dalam melaksanakan kegiatan bercerita mengakibatkan kurangnya kemampuan kinerja guru dalam mempersiapkan dan melaksanakan bercerita. Disamping itu, kegiatan bercerita pun menjadi kurang bermakna dikarenakan guru seringkali menggunakan kegiatan bercerita sebagai pengisi kekosongan waktu diawal atau akhir kegiatan saja. Sedangkan minat awal anak pada kegiatan bercerita cukup antusias, namun dikarenakan kurangnya perencanaan yang baik berakibat kurangnnya kemampuan anak dalam menyimak cerita. Maka mengenai hal tersebut,

pengembangan model bercerita berbasis VAK untuk memfasilitasi kemampuan menyimak anak dapat menjadi salah satu model pembelajaran untuk pengajaran guru kepada anak yang sesuai dengan kebutuhan gaya belajarnya yaitu modalitas visual, auditori, dan kinestetik.

B. Rancangan model bercerita berbasis VAK untuk memfasilitasi kemampuan menyimak anak pada kelompok B taman kanak kanak ini disusun berdasarkan temuan masalah di lapangan, serta hasil studi literatur. Perancangan model bercerita berbasis VAK ini terdiri dari perencanaan, pengembangan/pelaksanaan, dan evaluasi. Kemudian pengembangan modelnya pun disusun berdasarkan prinsip pada sintaks, prinsip reaksi, sistem sosial, dan sistem pendulamg. Setelah perancangan awal tersusun, peneliti melakukan tahap uji validitas atau uji kelayakan oleh validator yang ahli dalam bidang model pembelajaran anak usia dini dan bidang bahasa. Rekomendasi dari para ahli dijadikan masukan oleh peneliti untuk merevisi produk yang telah dirancang sehingga rancangan 
produk tersebut layak untuk diuji cobakan ke lapangan.

C. Ketercapaian anak dan guru pada pembelajaran uji coba model bercerita berbasis VAK untuk memfasilitasi kemampuan menyimak anak pada kelompok B taman kanak kanak mendapatkan hasil capaian yang positif. Meskipun pada tahap I produk masih memiliki beberapa kekurangan, namun produk mencapai kelayakan yang optimal bagi kebutuhan di lapangan pada uji coba tahap II berdasarkan hasil refleksi dan revisi bersama guru terkait dan pembimbing.

D. Rancangan akhir produk model bercerita berbasis VAK untuk memfasilitasi kemampuan menyimak anak pada kelompok B taman kanak kanak ini berupa buku panduan pegangan guru.

\section{DAFTAR PUSTAKA}

Bradekamp, S. (2007). Develpmentally Approriate Practice in Early Childhood. Washington D. C.: NAEYC.

DePorter, B. (2007). Quantum Teaching Mempraktikan Quantum Learning di Ruang-Ruang Kelas. Bandung: Kaifa.

Fauziah, S. F. (2018). The Effect of Professional Development on Preschool Teachers' Instructional Behaviours during Storybook Reading. (Skripsi). Universitas Pendidikan Indonesia Kampus Tasikmalaya.

Herrington, J. et al. (2007). Design-based research and doctoral students: Guidelines for preparing a dissertation proposal. Proceedings of World Conference on Educational Multimedia, Hypermedia and

Telecommunications (pp. 4089- 4097). Chesapeake, VA: AACE.

Kemendikbud. 2014. Peraturan Menteri Pendidikan dan Kebudayaan Republik Indonesia Nomor 146 Tentang Kurikulum 2013 PAUD. Jakarta: Kementrian Pendidikan dan Kebudayaan.

Kurniawan, A. (2018). Metodologi Penelitian Pendidikan. Bandung: PT. Remaja Rosdakarya.

Madyawati, L. (2017). Strategi Pengembangan Bahasa pada Anak. Jakarta: Kencana.

Meilana, D. R. (2018). Optimalisasi Pengendalian Emosi Anak Inklusif Cerebral Palsy dengan Metode Bercerita Ekspresif Kelompok B di TK Persis Tarogong Garut. (Skripsi). Universitas Pendidikan Indonesia Kampus Tasikmalaya.
Plomp. (2007). "Educational Design Research: An Introduction", dalam An Introduction to Educational Research. Enschede, Netherland: National Institute for Curriculum Development.

Roestiyah. (2008). Strategi Belajar Mengajar. Jakarta: Rineka Cipta.

Said, A. \& Budimanjaya, A. (2017). 95 Strategi Mengajar Multiple Intelligences Mengajar Sesuai Kerja Otak dan Gaya. Jakarta: Kencana.

Santrock, J. W. (2017). Perkembangan Anak. Jakarta: Erlangga.

Stockall, N., \& Dennis, L. (2012). Fathers' role in play; enhancing early language and literacy of children with developmental delays. Early Childhood Educ J. (41), .299-306.

Sugiyono. (2017). Metode Penelitian Pendidikan. Bandung: Alfabeta.

Van Den Akker, J. et al. (2006). Educational Design Research. USA and Canada: Routledge. 